\title{
Infection patterns of Paradollfusnema amphisbaenia (Nematoda: Cosmocercidae) in a population of Amphisbaena wuchereri (Squamata: Amphisbaenidae) from Minas Gerais state, south-eastern Brazil, and its relations with host size, sex and fat body mass
}

\author{
R. Filogonio ${ }^{1 *}$, G.M. Toledo ${ }^{2}$, L.A. Anjos ${ }^{2}$, B. Rajão ${ }^{3}$, \\ C.A.B. Galdino ${ }^{4}$ and L.B. Nascimento ${ }^{4,5}$ \\ ${ }^{1}$ Departamento de Zoologia, UNESP - Universidade Estadual Paulista, \\ Campus Rio Claro, Instituto de Biociências, Rio Claro, São Paulo, Brasil: \\ ${ }^{2}$ Departamento de Parasitologia, UNESP - Universidade Estadual \\ Paulista, Campus Botucatu, Instituto de Biociências, Botucatu, São Paulo, \\ Brasil: ${ }^{3}$ Funcesi/Fisa, Laboratório de Morfologia, Itabira, Minas Gerais, \\ Brasil: ${ }^{4}$ Programa de Pós-Graduação em Zoologia de Vertebrados, \\ Pontifícia Universidade Católica de Minas Gerais, Belo Horizonte, Minas \\ Gerais, Brasil: ${ }^{5}$ Museu de Ciências Naturais, Pontifícia Universidade \\ Católica de Minas Gerais, Belo Horizonte, Minas Gerais, Brasil
}

(Received 8 August 2011; Accepted 24 November 2011; First Published Online 5 January 2012)

\begin{abstract}
Specimens $(n=41)$ of the amphisbaenid Amphisbaena wuchereri taken from a population in Minas Gerais state, south-eastern Brazil, were examined for gastrointestinal parasites. A single nematode species was found, Paradollfusnema amphisbaenia. This was a new host record for this nematode species. This parasite was encountered in the large intestine (prevalence of $100 \%$ ), in the stomach (prevalence of $2 \%$ ) and in the small intestine (prevalence of $7.3 \%$ ). The intensity of infection ranged from 1 to 457 individual parasites per host and was positively correlated with body size of both male and female amphisbaenians. The discrepancy index $(D)$ indicated that $P$. amphisbaenia tended to an even distribution in this host population. The nematode, which did not affect fat body mass, induced inflammatory infiltrations in the small intestine, indicating that the parasites might injure the host's organs.
\end{abstract}

\section{Introduction}

Ecological interactions between parasites and neotropical reptiles have been the subject of a number of recent studies (e.g. Anjos et al., 2005; Almeida et al.,

*E-mail: renatofilogonio@gmail.com
2007, 2008; Ávila \& Silva, 2010). In general, the number of parasites infecting a single host (i.e. intensity of infection) is related to individual body size, with larger individuals having higher parasite loads, possibly because of increased chances of infection during longer lifespans or due to niche divergences between juveniles and adults (Rocha, 1995). Differences in prey selection may also be a reason to explain any sex-based 
differences in prevalence and intensity of infection in reptiles (Ribas et al., 1995).

Endoparasites obtain all their nutrients from their hosts, and nematodes may feed on the intestinal contents or on the host tissues (Quinnell et al., 1990), which may induce energetically costly immunological responses (Lochmiller \& Deerenberg, 2000) leading to deficits in energy budgets of their hosts. Thereby, parasitized individuals might have less energy to invest in reproduction (Polack, 1998; Bollache et al., 2001), physiology (Hernández-Bello et al., 2010), behaviour (De Jong-Brink \& Koene, 2005) and ultimately survival (Fuller \& Blaunstein, 1996), affecting the overall fitness of hosts (Schüpbach \& Baur, 2008; Thomas et al., 2010). For reptiles, authors have found different responses of hosts to parasites. For example, Hidalgo-Vila et al. (2011) reported that the nematode Serpinema microcephalus caused pancreatitis in red-eared slider turtles, Trachemys scripta elegans, with tissue destruction and inflammation. Madsen et al. (2005) found that the intensity of infection of a hematozoan blood parasite is negatively correlated with growth and condition in water pythons, Liasis fuscus. On the other hand, in the lizard Lacerta vivipara, blood parasite load was positively related to the relative clutch mass and investment per young in female lizards (Sorci et al., 1996).

Amphisbaenians are fossorial reptiles and their burrowing habit presents difficulties when collecting large series of individuals from their natural environment. Hence, information regarding infection patterns for this reptile group is scarce. Nevertheless, studies have demonstrated that amphisbaenians may have an important role as hosts in the life cycle of some parasite species. For example, the species Amphisbaena alba is the final host of the pentastomid Raillietiella gigliolii (Winch \& Riley, 1985), and may show high prevalences of this nematode species (from 55\% (Almeida et al., 2009) to 86\% (Winch \& Riley, 1985)) and an intensity of infection from 1 to 13 parasites (Almeida et al., 2009).

The aim of the present study was to analyse the gastrointestinal helminth infection patterns in a population of the shovel-snouted amphisbaenid Amphisbaena wuchereri by measuring the level of aggregation (i.e. aggregation of parasites within the host population; Poulin, 1993), the prevalence and mean intensity of infection of parasites. Since females are larger than males in A. wuchereri (Filogonio et al., 2009), we compared the relative parasite load between the sexes. Additionally, we tested the effect of helminth loads on the storage of fat in the amphisbaenians. Reptiles typically have coelomic fat bodies and their size may represent the stored energy remaining from that spent on maintenance metabolism and growth, indicating the condition of the organism (Hayes \& Shonkwiler, 2001).

\section{Materials and methods}

\section{Collection and examination of reptiles}

Amphisbaenians in this study were collected by animal rescue groups, in October and November 2001, during the flooding process leading to the construction of the Santa Clara hydroelectric power plant in the municipalities of Nanuque and Serra dos Aimorés, Minas Gerais state, south-eastern Brazil $\left(17^{\circ} 50^{\prime} \mathrm{S}, 40^{\circ} 21^{\prime} \mathrm{W}\right)$. This site is situated within the Atlantic rainforest biome and possessed forest fragments that were damaged as a result of timber extraction. Captured animals were transported to the hydroelectric laboratory and maintained in a ventilated wooden collection box $(40 \times 20 \times 20 \mathrm{~cm})$ for $2-3$ days and were not fed during this period. Wet cotton pads were placed in the box to maintain humidity. Individuals were subsequently euthanized, fixed in 10\% formalin, kept in a storage solution of $70 \%$ alcohol, and deposited at Museu de Ciências Naturais, Pontifícia Universidade Católica de Minas Gerais (MCNR 279-425), Brazil.

Prior to dissection in the laboratory, we measured the snout to vent length (SVL), subtracting tail length (measured with a caliper to the nearest $0.05 \mathrm{~mm}$ from the extreme posterior point of the cloacal flap to the tip ofthe tail) from total length (measured with a measuring tape to the nearest $1 \mathrm{~mm}$ ). Individuals were sexed by verifying the presence or absence of the everted hemipenis. The gonads were examined in individuals in which the hemipenis was not present in order to positively assign a sex to each individual. During dissections, we first removed the fat bodies located within the body cavity and dried them with paper towels for $c .30 \mathrm{~min}$ prior to weighing with a precision balance to the nearest $0.1 \mathrm{mg}$. Since fat body mass (FBM) can be affected by reproductive stage in squamate reptiles (e.g. Van Sluys et al., 2002; Galdino et al., 2003) we inspected gonads in order to verify reproductive condition of $A$. wuchereri. The gonads showed no overt sign of reproductive activity (see Filogonio et al., 2009). Hence, we are confident that all individuals of A. wuchereri were non-reproductive and, consequently, that FBM was not influenced by differences in reproductive state between individuals.

The gastrointestinal tract (stomach and small and large intestines) were removed and checked under a stereomicroscope for the presence of helminths. The taxonomic determination of helminths was carried out by morphological characters following Vicente et al. (1993) and Bursey (2002). Parasites were cleared with lactophenol and analysed under a light microscope with the Leica Application Suite (LAS V5) computerized system (Leica Microsystems, Wetzlar, Germany). For each helminth species, we calculated the prevalence [(infected amphisbaenians/examined amphisbaenians) $\times$ 100] (Bush et al., 1997) and the mean intensity of infection (arithmetic mean number of worms from infected amphisbaenians) (Bush et al., 1997). Voucher specimens of the helminths were deposited at the Coleção Helmintológica do Instituto de Biociências (CHIBB, no. 5098-5099), Universidade Estadual Paulista - UNESP, Brazil.

\section{Data analysis}

Preliminary analyses were performed to test the normality and homoscedasticity of data and to choose the appropriate statistical tests. Descriptive statistics are presented as mean \pm standard error (according to Bush et al., 1997). The Spearman's Rank Correlation and Pearson's Correlation (Zar, 1999) were used to evaluate the association between host size (SVL) and infection intensities in males and females, respectively. Differences 
in intensity of infection between sexes were tested using Mann-Whitney $U$-test. The discrepancy index $(D)$, used to measure the level of aggregation, was calculated according to the equation:

$$
D=1-\frac{2 \sum_{i=1}^{N}\left(\sum_{j=1}^{i} x_{j}\right)}{\bar{x} N(N+1)}
$$

where $x$ is the number of parasites in host $j$ (hosts are ranked from the least to most infected) and $N$ is the total number of hosts (Poulin, 1993). The index has a minimum value of zero $(D=0)$ if all hosts harbour the same number of parasites, and a maximum value $(D=1)$ if all parasites were found in a single host. This index was calculated with the software Quantitative Parasitology 3.0 (Rózsa et al., 2000).

Mass is a function of body size (Le Cren, 1951; Hayes \& Shonkwiler, 2001) and parasite intensity has been positively correlated with body size in a number of reptile species (e.g. Van Sluys et al., 1994, 1997; Vrcibradic et al., 2000, 2002). Thus, comparisons between FBM and parasite intensity can be confounded by variations in body size. In order to minimize the effect of size on the relationship between parasite load and FBM only the 10 longest individuals of each sex were used to perform a linear regression of these variables. We used this methodology to meet the assumption of independency between size and mass pointed out by Green (2001) for body condition analysis (see Results). Prior to analysis, FBM was cubic root transformed. The effect of parasites on FBM was tested for males and females separately.

\section{Results}

The study utilized 41 individuals of $A$. wuchereri. From these, 23 individuals were males $(290 \pm 15.0 \mathrm{~mm}$ SVL) and 18 females $(352.1 \pm 11.1 \mathrm{~mm}$ SVL). The only parasite found in the gastrointestinal tract of $A$. wuchereri was the nematode Paradollfusnema amphisbaenia (Nematoda: Cosmocercidae). All amphisbaenians were parasitized by at least one individual of $P$. amphisbaenia (overall prevalence $=100 \%$ ). The mean intensity of infection was $116.2 \pm 16.6$ (range $1-467$ ). The male hosts' mean intensity of infection was $110.7 \pm 24.6$ (range 1-467) and the females' mean intensity of infection was $130.0 \pm 21.9$ (range 11-317). However, this difference was not statistically significant (Mann-Witney; $U=174 ; P=0.2$ ). We also checked for differences in intensity of infection between the ten longest individuals of each sex and we found no intersexual difference $(t=-1.23, \mathrm{df}=18, P=0.23)$.

Regarding the infection sites, parasites were located in the large intestine of all host specimens (i.e. a prevalence of $100 \%)$. The mean intensity of infection in this site was $113.6 \pm 16.8$ (range 1-467). An infection range of 5-12 was found in the small intestine (prevalence of $7.3 \%$ ), and one parasite was found in the stomach (prevalence of $2 \%$ ). The body size of the amphisbaenian host had a positive influence on the intensity of infection (Spearman's rank correlation, $\left.r_{s}=0.70, P<0.0001, n=41\right)$, in both male hosts (Spearman's rank correlation, $r_{s}=0.78, P<0.0001$, $n=23$ ) and female hosts (Spearman's rank correlation, $r_{s}=0.57, P<0.01, n=18$ ) (fig. 1). The discrepancy index
(D) for male hosts was $D=0.51$ and for female hosts, $D=0.39$. Overall discrepancy was $D=0.47$.

In the ten longest individuals of each sex (body size range $310.90-388.85 \mathrm{~mm}, 359.10 \pm 23.33$, SVL of males; body size range $337.10-432.05 \mathrm{~mm}, 373.54 \pm 28.8$, SVL of females), SVL was not correlated with FBM $\left(r^{2}=0.08\right.$, $P=0.27, n=20)$ or parasite intensity $\left(r^{2}=0.06, P=0.15\right.$, $n=20)$. Hence, our analysis was not confounded by size effects and met the assumption of independency between size and mass for body condition analysis (Green, 2001). Males' FBM ranged from 0.56 to $4.53 \mathrm{~g}(1.90 \pm 1.38 \mathrm{~g})$ and females' FBM ranged from 1.20 to $4.50 \mathrm{~g}(2.75 \pm 1.04 \mathrm{~g})$ and, in both cases, FBM was not associated with parasite intensity (Spearman's rank correlation, $r_{s}=0.24$, $P=0.28, n=10$, for males; Pearson's correlation, $r=0.37, P=0.14, n=10$, for females).

\section{Discussion}

Although other helminth species are known to infect amphisbaenians (Ávila \& Silva, 2010), the nematode

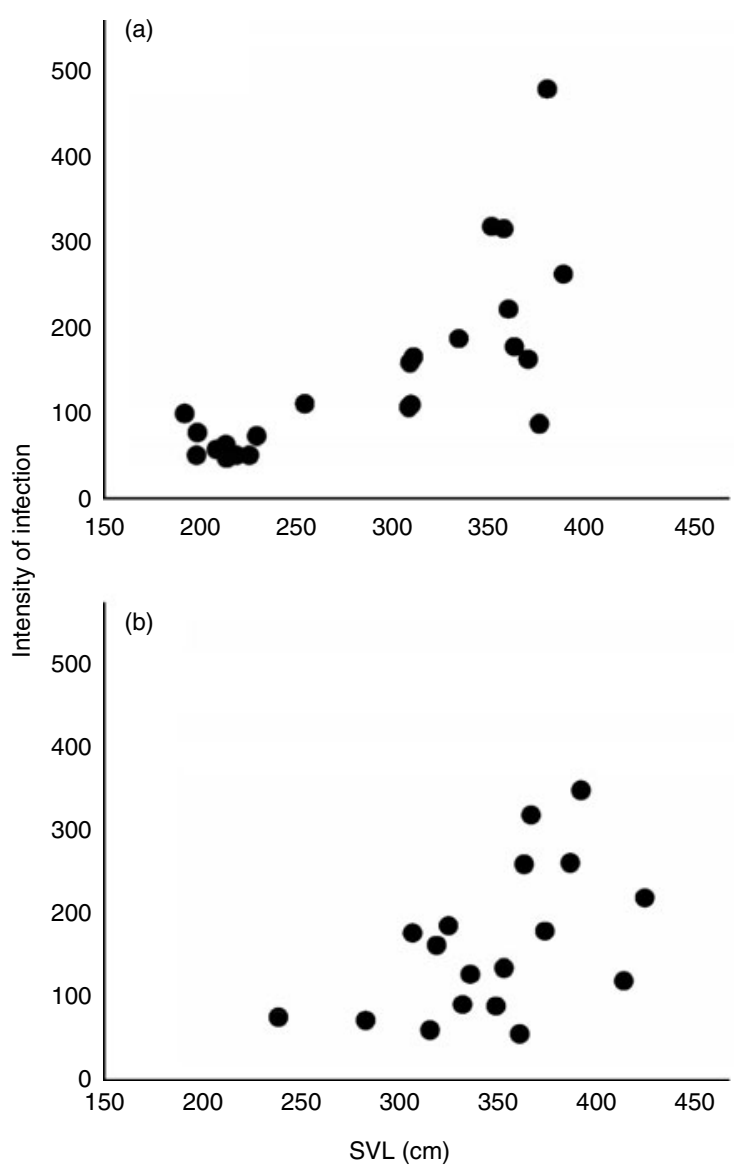

Fig. 1. Correlation between snout to vent length (SVL) and intensity of infection of Paradollfusnema amphisbaenia infecting Amphisbaena wuchereri at Minas Gerais state, Brazil. Spearman's rank correlation between SVL and intensity of infection to male hosts (a) $r_{s}=0.78, P<0.05, n=23$; and to female hosts (b) $r_{\mathrm{s}}=0.57, P<0.01, n=18$. 
fauna found in the sampled population of $A$. wuchereri was composed solely of the species $P$. amphisbaenia. Paradollfusnema was created by Baker (1982) as a nomen novum replacing Dollfusnema Baker, 1981, preoccupied by Dollfusnema Caballero, 1974. There are two species in this genus, $P$. amphisbaenia, from the Brazilian amphisbaenian Amphisbaena microcephala (= Leposternon phocaena Duméril and Bibron, 1839) (Vicente et al., 1993), and the most recently described species Paradollfunsnema tellfordi Bursey, 2002 from the amphisbaenian Rhineura floridana from Florida, USA (Bursey, 2002). Hence, this finding constitutes a register of a new host for P. amphisbaenia and also extends its range of occurrence through southeastern Brazil.

Amphisbaena wuchereri presented high prevalence $(100 \%)$ and intensity of infection when compared to previous studies of parasitism of amphisbaenians. For example, Blanus strauchi presented a prevalence of $70 \%$ and the intensity of infection varied from one to two gastrointestinal helminths (Düşen et al., 2010); R. floridana had a prevalence of $50 \%$ and intensity of infection of one parasite per host infected (Telford \& Bursey, 2003). The very high prevalence of $P$. amphisbaenia in $A$. wuchereri rules this out as an incidental case of parasitism and suggests that $A$. wuchereri constitutes a specific host for this helminth species.

As for other reptile species, intensity of infection was positively associated with the host's body size, evidencing ontogenetic differences in intensity of infection. Age differences in intensity of infection can be assigned to an increase in the chances of acquiring parasites during the lifetime of larger (i.e. older) lizards (Vrcibradic et al., 1999). Another hypothesis explaining ontogenetic differences in intensity of infection of parasites is that it might emerge as a consequence of segregation in diet between smaller (young) and larger (adults) individuals (Rocha, 1995). Unfortunately, due to the 3-day fasting period prior to killing for preservation, and the bad conservation of stomach contents, we were not able to evaluate dietary composition.

There were no differences in the intensity of parasite infection between males and females despite the females being longer than males (Filogonio et al., 2009). Sexual size dimorphism can lead to different microhabitat utilization (Schoener, 1968) or to segregation in diet between sexes (Gomes et al., 2009). Such ecological segregation is argued in the literature to be an important factor in determining patterns of intensity of infection and prevalence in reptiles (Ribas et al., 1995; Anjos et al., 2005). However, several studies have suggested that other factors might also be involved in determining infection patterns in reptiles. For example, for the lizard species Eurolophosaurus nanuzae (Fontes et al., 2003) and Mabuya frenata (Vrcibradic et al., 1999), intersexual differences in prevalence were encountered despite the apparent absence of ecological divergences between sexes regarding diet, microhabitat use and active body temperatures (Kiefer, 1998; Vrcibradic \& Rocha, 1998). Moreover, for the lizard Anolis lineatopus, intersexual differences in intensity of infection were suggested to be a consequence of divergent environment use between sexes, or to different genetic susceptibility of the host population, or a combination of both factors (Vogel \& Bundy, 1987). It seems that if there is any ecological divergence between sexes in this population of $A$. wuchereri as a consequence of sexual dimorphism, it is not expressed in the prevalence or intensity of infection. The scarcity of basic life-history data regarding amphisbaenians, especially A. wuchereri, precludes any further ecological inferences.

The habitat for the parasites is not spatially continuous and consists of cells or discrete 'islands' (i.e. the hosts represent patches of favourable habitat in an uninhabitable environment). The parasites are not evenly distributed in these islands, as individual hosts contain very different numbers of parasites. Thus, parasite populations are frequently more aggregated among their hosts than if they were randomly distributed (Poulin, 1993, 2007). Paradollfusnema amphisbaenia presented a rather homogeneous distribution in this host sample, with a tendency to be more aggregated in male hosts. According to Poulin (1993), more prevalent parasites show lower $D$ values. Our results support this presumption as in this $A$. wuchereri population the prevalence was high $(100 \%)$ and the $D$ value indicated an even distribution of parasites. Amphisbaena wuchereri is a highly specialized digger (Gans, 1971) and the environment under the soil might be rather homogeneous, which would preclude significant differentiation in individual habitat use and, consequently, infection patterns.

Parasitism can be negatively related to host's life history (e.g. Bosch et al., 2000). However, despite the high infection rates found for $A$. wuchereri, intensity of infection was not associated with its FBM. Nevertheless, we found inflammatory infiltrations in the large intestine of infected individuals of $A$. wuchereri (Rajão, unpublished data). Additionally, we must consider that FBM could be biased by the 3-day fasting period that individuals were submitted to (see Materials and methods), leading us to incur a Type II error. If this is the case, it is possible that $P$. amphisbaenia is harming individuals of $A$. wuchereri to some degree.

\section{Acknowledgements}

We thank Edwin W. Taylor and Cláudio J. Von Zuben for their kind suggestions on the preparation of this manuscript. R.F. received an MSc scholarship from Conselho Nacional de Desenvolvimento Científico e Tecnológico (CNPq; \#131220/2010-1); L.A.A., a postdoctoral grant from Fundação de Amparo à Pesquisa do Estado de São Paulo (FAPESP; \# 08/50417-7); C.A.B.G., a postdoctoral grant from CNPq (\#151663/2010-6); and L.B.N., financial support from Fundação de Amparo à Pesquisa do Estado de Minas Gerais (FAPEMIG).

\section{References}

Almeida, W.O., Vasconcelos, A., Freire, E.M.X. \& Lopes, S.G. (2007) Prevalence and intensity of pentastomid infection in two species of snakes from northeast Brazil. Brazilian Journal of Biology 67, 759-763.

Almeida, W.O., Costa, T.B.G., Freire, E.M.X. \& Vasconcelos, A. (2008) Pentastomid infection in Philodryas nattereri Steindachner, 1870 and Oxybelis 
aeneus (Wagler, 1824) (Squamata: Colubridae) in a Caatinga of northeastern Brazil. Brazilian Journal of Biology 68, 193-197.

Almeida, W.O., Sales, D.L., Santana, G.G., Vieira, W.L.S., Ribeiro, S.C., Alves, R.R.N. \& Nóbrega, R.P. (2009) Prevalence and intensity of infection by Raillietiella gigliolii Hett, 1924 (Pentastomida) in Amphisbaena alba Linnaeus, 1758 and A. vermicularis Wagler, 1824 (Amphisbaenidae) from Northeastern Brazil. Brazilian Journal of Biology 69, 1183-1186.

Anjos, L.A., Rocha, C.F.D., Vrcibradic, D. \& Vicente, J.J. (2005) Helminths of the exotic lizard Hemidactylus mabouia from a rock outcrop area in southeastern Brazil. Journal of Helminthology 79, 307-313.

Ávila, R. \& Silva, R. (2010) Checklist of helminths from lizards and amphisbaenians (Reptilia, Squamata) of South America. Journal of Venomous Animals and Toxins Including Tropical Diseases 16, 543-572.

Baker, M.R. (1982) Systematic relationships of the Atractidae and Cosmocercidae (Nematoda: Cosmocercoidea); two new atractids parasitic in amphibians and fish. Canadian Journal of Zoology 60, 2395-2402.

Bollache, L., Gambade, G. \& Cézilly, F. (2001) The effects of two acanthocephalan parasites, Pomphorhynchus laevis and Polymorphus minutus, on pairing success in male Gammarus pulex (Crustacea: Amphipoda). Behavioral Ecology and Sociobiology 49, 296-303.

Bosch, M., Torres, J. \& Figurola, J. (2000) Helminth community in breeding yellow-legged gulls (Larus cachinnans): pattern of association and its effects on host's fitness. Canadian Journal of Zoology 78, 777-786.

Bursey, C.R. (2002) Paradollfusnema telfordi n. sp. (Nematoda: Cosmocercidae) from the worm lizard, Rhineura floridana (Amphisbaenia), of Florida. Journal of Parasitology 88, 554-556.

Bush, A.O., Lafferty, K.D., Lotz, J.M. \& Shostak, A.W. (1997) Parasitology meets ecology on its own terms: Margolis et al. revisited. Journal of Parasitology 83, $575-583$.

De Jong-Brink, M. \& Koene, J.M. (2005) Parasitic manipulation: going beyond behaviour. Behavioural Processes 68, 229-233.

Düşen, S., Uğurtaş, I.H. \& Aydoğdu, A. (2010) Nematode parasites of the two limbless lizards: Turkish worm lizard, Blanus strauchi (Bedriaga, 1884) (Squamata: Amphisbaenidae), and slow worm, Anguis fragilis Linnaeus 1758 (Squamata: Anguidae), from Turkey. Helminthologia 47, 158-163.

Filogonio, R., Galdino, C.A.B., Cabral, D.P.R., Righi, A.F., Lopes, M.F. \& Nascimento, L.B. (2009) Sexual dimorphism in Leposternon microcephalum and $L$. wuchereri (Squamata: Amphisbaenidae) from Minas Gerais, southeastern Brazil. Herpetologica 65, 353-362.

Fontes, A.F., Vicente, J.J., Kiefer, M.C. \& Van Sluys, M. (2003) Parasitism by helminths in Eurolophosaurus nanuzae (Lacertilia: Tropiduridae) in an area of rocky outcrops in Minas Gerais state, southeastern Brazil. Journal of Herpetology 37, 736-741.

Fuller, C.A. \& Blaustein, A.R. (1996) Effects of the parasite Eimeria arizonensis on survival of deer mice (Peromyscus maniculatus). Ecology 77, 2196-2202.

Galdino, C.A.B., Assis, V.B., Kiefer, M.C. \& Van Sluys, M. (2003) Reproduction and fat body cycle of
Eurolophosaurus nanuzae (Sauria; Tropiduridae) from a seasonal montane habitat of southeastern Brazil. Journal of Herpetology 37, 687-694.

Gans, C. (1971) Studies on amphisbaenians (Amphisbaenian: Reptilia). 4. A review of the amphisbaenid genus Leposternon. Bulletin of the American Museum of Natural History 144, 379-464.

Gomes, J.O., Maciel, A.O., Costa, J.C.L. \& Andrade, G.V. (2009) Diet composition of two sympatric amphisbaenian species (Amphisbaena ibijara and Leposternon polystegum) from the Brazilian cerrado. Journal of Herpetology 43, 377-384.

Green, A.J. (2001) Mass/length residuals: measures of body condition or spurious results? Ecology 82, 1473-1483.

Hayes, J.P. \& Shonkwiler, J.S. (2001) Morphometric indicators of body condition: worthwhile or wishful thinking? pp. 8-38 in Speakman, J.R. (Ed.) Body condition analysis of animals: A handbook of nondestructive methods. Cambridge, Cambridge University Press.

Hernández-Bello, R., Escobedo, G., Guzmán, C., IbarraCoronado, E.G., López-Griego, L. \& Morales-Montor, J. (2010) Immunoendocrine host-parasite interactions during helminth infections: from the basic knowledge to its possible therapeutic applications. Parasite Immunology 32, 633-643.

Hidalgo-Vila, J., Martínez-Silvestre, A., Ribas, A., Casanova, J.C., Pérez-Santigosa, N. \& Díaz-Paniagua, C. (2011) Pancreatitis associated with the helminth Serpinema microcephalus (Nematoda: Camallanidae) in exotic red-eared slider turtles (Trachemys scripta elegans). Journal of Wildlife Deseases 47, 201-205.

Kiefer, M.C. (1998) Dieta, modo de forrageamento e uso de microhábitat em duas espécies simpátricas de Tropidurus (Sauria: Tropiduridae) na Serra do Cipó, Minas Gerais. MSc Dissertation, Universidade Estadual Paulista, Rio Claro, São Paulo, Brazil.

Le Cren, E.D. (1951) The length-weight relationship and seasonal cycle in gonad weight and condition in the perch (Perca fluviatilis). Journal of Animal Ecology 20, 201-219.

Lochmiller, L.R. \& Deerenberg, C. (2000) Trade-offs in evolutionary immunology: just what is the cost of immunity? Oikos 88, 87-98.

Madsen, T., Ujvari, B. \& Olsson, M. (2005) Old pythons stay fit; effects of haematozoan infections on life history traits of a large tropical predator. Oecologia 142, 407-412.

Polack, M. (1998) Effects of ectoparasitism on host condition in the Drosophila-Macrocheles system. Ecology 79, 1807-1817.

Poulin, R. (1993) The disparity between observed and uniform distributions: a new look at parasite aggregation. International Journal of Parasitology 23, 937-944.

Poulin, R. (2007) Evolutionary ecology of parasites. 332 pp. New Jersey, Princeton University Press.

Quinnell, R.J., Medley, G.F. \& Keymer, A.E. (1990) The regulation of gastrointestinal helminth populations. Philosophical Transactions: Biological Sciences 330, 191-201.

Ribas, S.C., Rocha, C.F.D., Teixeira, P.F. \& Vicente, J.J. (1995) Helminths (Nematoda) of the lizard 
Cnemidophorus ocellifer (Sauria: Teiidae): assessing the effects of rainfall, body size and sex in the nematode infection rates. Ciência e Cultura 47, 88-91.

Rocha, C.F.D. (1995) Nematode parasites of the Brazilian sand lizard, Liolaemus lutzae. Amphibia-Reptilia 16, 412-415.

Rózsa, L., Reiczigel, J. \& Majoros, G. (2000) Quantifying parasites in samples of hosts. Journal of Parasitology 86, $228-232$.

Schoener, T.W. (1968) The Anolis lizards of Bimini: resource partitioning in a complex fauna. Ecology 49, $704-726$.

Schüpbach, H.U. \& Baur, B. (2008) Parasitic mites influence fitness components of their host, the land snail Arianta arbustorum. Invertebrate Biology 127, 350-356.

Sorci, G., Clobert, J. \& Michalakis, Y. (1996) Cost of reproduction and cost of parasitism in the common lizard Lacerta vivipara. Oikos 76, 121-130.

Telford, S.R. Jr \& Bursey, C.R. (2003) Comparative parasitology of squamate reptiles endemic to scrub and sandhills communities of north-central Florida, U.S.A. Comparative Parasitology 70, 172-181.

Thomas, F., Poulin, R. \& Brodeur, J. (2010) Host manipulation by parasites: a multidimensional phenomenon. Oikos 119, 1217-1223.

Van Sluys, M., Rocha, C.F.D. \& Ribas, S. (1994) Nematodes infecting the lizard Tropidurus itambere in southeastern Brazil. Amphibia-Reptilia 15, 405-408.

Van Sluys, M., Rocha, C.F.D., Bergallo, H.G., Vrcibradic, D. \& Ribas, S.C. (1997) Nematode infection in three sympatric lizards in an isolated fragment of restinga habitat in southeastern Brazil. Amphibia-Reptilia 18, 442-446.

Van Sluys, M., Mendes, H.M.A., Assis, V.B. \& Kiefer, M.C. (2002) Reproduction of Tropidurus montanus Rodrigues, 1987 (Tropiduridae), a lizard from a seasonal habitat of southeastern Brazil, and a comparison with other Tropidurus species. Herpetological Journal 12, 89-97.

Vicente, J.J., Rodrigues, H.O., Gomes, D.C. \& Pinto, R.M. (1993) Nematóides do Brasil. Parte III: Nematóides de répteis. Revista Brasileira de Zoologia 10, 19-168.

Vogel, P. \& Bundy, D.A.P. (1987) Helminth parasites of Jamaican anoles (Reptilia: Iguanidae): variation in prevalence and intensity with host age and sex in a population of Anolis lineatopus. Parasitology 94, 399-404.

Vrcibradic, D. \& Rocha, C.F.D. (1998) The ecology of the skink Mabuya frenata in an area of rock outcrops in southeastern Brazil. Journal of Herpetology 32, 229-237.

Vrcibradic, D., Rocha, C.F.D., Ribas, S.L. \& Vicente, J.J. (1999) Nematodes infecting the skink Mabuya frenata in Valinhos, São Paulo state, southeastern Brazil. Amphibia-Reptilia 20, 333-339.

Vrcibradic, D., Cunha-Barros, M., Vicente, J.J., Galdino, C.A.B., Hatano, F.H., Van Sluys, M. \& Rocha, C.F.D. (2000) Nematode infection patterns in four sympatric lizards from a restinga habitat (Jurubatiba) in Rio de Janeiro state, southeastern Brazil. Amphibia-Reptilia 21, 307-316.

Vrcibradic, D., Rocha, C.F.D., Bursey, C.R. \& Vicente, J.J. (2002) Helminths infecting Mabuya agilis (Lacertilia, Scincidae) in a 'restinga' habitat (Grumari) of Rio de Janeiro, Brazil. Amphibia-Reptilia 23, 109-114.

Winch, J.M. \& Riley, J. (1985) Experimental studies on the life-cycle of Raillietiella gigliolii (Pentastomida: Cephalobaenida) in the South American worm-lizard Amphisbaena alba: a unique interaction involving two insects. Parasitology 91, 471-481.

Zar, J.H. (1999) Biostatistical analysis. Englewood Cliffs, New Jersey, Prentice Hall. 